\title{
Multi-level, Multi-actor and Multi-issue Dimensions of Governance of the European Higher Education Area, and Beyond
}

\author{
Martina Vukasovic, Jens Jungblut, Meng-Hsuan Chou, Mari Elken \\ and Pauline Ravinet
}

\section{Introduction}

With massification and increasing focus on knowledge as the foundation for inclusive and sustainable social, cultural, political as well as economic development, higher education has become more salient and politicized (Busemeyer et al. 2013; Gornitzka and Maassen 2014; Jungblut 2015). In this chapter, we employ a novel framework (Chou et al. 2017) that provides the analytical precision required to dissect and examine these developments and unpack their implications for the future development of the European Higher Education Area (EHEA).

To start with, the centrality of knowledge implies that decisions (planned as well as those already taken) concerning higher education are more connected to policy developments in many other sectors, such as research, welfare, environment,

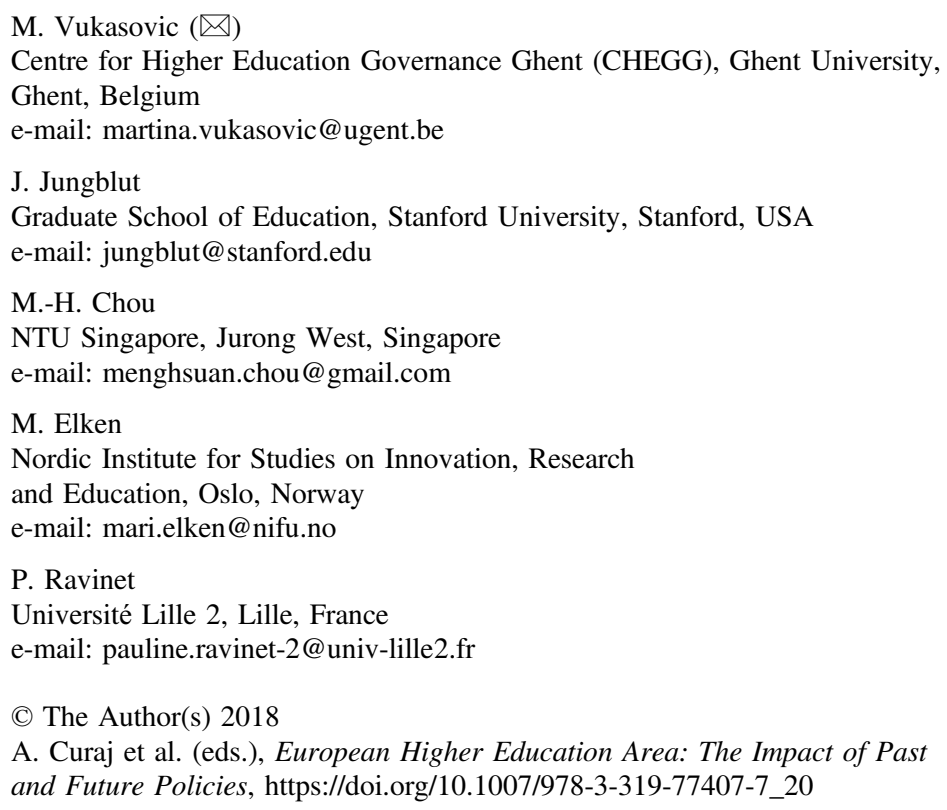


employment, trade, migration, or security. This means that, in higher education policy processes, multiple issues concerning a variety of sectors need to be considered, including horizontal tensions about jurisdiction and ownership. Coupled with this development are also upward and downward shifts in governance arrangements that characterize contemporary public policy making (Maassen 2003). The former concerns the institutionalization of governance arenas beyond the national level, e.g. through the Bologna Process, EU initiatives in higher education or similar macro-regional integration efforts in South-East Asia, Latin America, or sub-Saharan Africa (Chou and Ravinet 2015, 2017; Maassen and Olsen 2007). The latter reflects the wave of reforms increasing the formal autonomy of higher education institutions (HEIs), which are often coupled with changes in internal governance arrangements strengthening central leadership and administration (Christensen 2011; Maassen et al. 2017). The outcome is that governance takes place across multiple levels, potentially leading to vertical tensions concerning the distribution of authority. The third relevant development is the increasing participation and influence of multiple actors in higher education governance. This concerns a variety of non-state actors, such as universities, student and staff unions, business associations and other stakeholder organizations, as well as state actors coming from different ministries or agencies. While these actors may focus on similar issues, they are likely to have different policy preferences that may be difficult to reconcile (Vukasovic 2017). Moreover, they will also differ with regard to access as well as organizational and political capacity to influence decision-making, implying that tensions with regards to power and preferences are also present in higher education governance.

Each of these developments - multi-issue, multi-level and multi-actor-has been the focus of much research, albeit often in isolation from each other. In this chapter, we employ a novel conceptual framework for analysing these three "multi-s" and their interactions, and we demonstrate how such a framework enables a more nuanced analysis of policy dynamics in European higher education, by focusing on three interrelated topics: (1) political salience of the Bologna Process, (2) the role and impact of European stakeholder organizations and their members across governance levels, and (3) relationship between European and regional policy coordination and convergence. These three examples provide a basis for the reflections on possible future developments of the Bologna Process and the analytical toolbox that could be employed to study these developments.

\section{Conceptualizing the Three "Multi-S"}

Of the three "multi-s" highlighted here, most of the research in higher education, as well as more generally in social sciences, has focused on the multi-level aspect. In this respect, the concept of multi-level governance (MLG) has become a taken-for-granted perspective to describe policy coordination across different governance levels, in particular in the European context. According to one of the most cited contributions on MLG- "Unravelling the Central State, but How" by 
Hooghe and Marks (2003) - two distinct types of multi-level governance can be identified: one in which different levels of authority are neatly nested within each other and which is designed to comprise an entire fixed system of governance (Type I, e.g. typical federalist structure), and the other in which the focus is on task jurisdictions which may change should the need arise and where jurisdictions may overlap (Type II). While often used, the challenge with this dichotomous categorization is that multiple Type II governance arrangements are in place for achieving an overarching common objective of European Higher Education and Research Areas, and the typology does not allow for exploring the implications of such multiplicity. For example, efforts to construct a common area of knowledge in Europe (see "Europe of Knowledge" in Chou and Gornitzka 2014) encompass developments in the higher education policy sector (i.e. EHEA), in the research policy sector (European Research Area, ERA), and in the innovation policy sector (now the Innovation Union, which also incorporates the ERA). What is notable about these developments is that each set of sectoral governance arrangements follows a distinct method of coordination and upholds their individual sectoral rationales, even though policy reforms have been introduced to promote coherent coordination across these sectors. Thus, it is necessary to look beyond this typology.

The popularity of MLG as a concept also means that it has been a subject to concept stretching. Trying to redress this issue, Piattoni (2010) focused on its conceptual, empirical, and normative aspects and proposed three MLG dimensions: (1) domestic-international, reflecting the emergence of governance layers beyond the nation state, (2) centre-periphery concerning the devolution of authority to local actors and key organizations (in this case higher education institutions), and (3) state-society referring to the involvement of both state and non-state actors. This means that the involvement of multiple actors is, according to Piattoni, just one dimension of MLG. This is, in our view, problematic because the reference to "levels" effectively conflates at least two distinct developments: distribution of authority across governance levels which we refer to as the multi-level aspect, as well as participation and influence of both state and non-state actors - which we term the multi-actor aspect. These two aspects need to be conceptually distinct in order to allow for both nuance and robustness in analysis.

However, policy-making in higher education, regardless of levels or actors, does not concern higher education only. The fact that higher education is "exported" as a policy solution to other sectors, and that issues from these sectors are sometimes "imported" into the higher education sector as policy problems to be solved (e.g. finding a solution for global warming and society's energy needs) implies significant coordination challenges (Braun 2008; Chou and Gornitzka 2014). This in particular concerns what can be termed multi-issue aspects of governance, which can be illustrated through the following questions: (1) which issues should be dealt with exclusively within the higher education sector?, (2) in which issues should actors from other sectors be involved?, and (3) which issues are better addressed in another sector? These questions are not a purely technical matter but are also underlined by differences in perceived importance between sectors (e.g. finance 
usually trumps education), as well as a reconciliation of policy preferences between different actors. It is thus essential to also make explicit the multi-issue feature in addition to the two other "multi-s"-multi-level and multi-actor-because this characteristic often masks the hidden strategies that policy actors apply to achieve their sectoral goals and objectives in another policy domain (Chou 2012).

To sum up, we posit three conceptually distinct characteristics of higher education governance (see also Chou et al. 2017) that also have implications for the analyses of dynamics within the EHEA:

1. Multi-level characteristic - the focus is on the processes leading to distribution or concentration of authority at different governance levels and the subsequent consequences of these processes. The key is to identify governance levels based on the existence of institutionalized governing structures, regardless of their formal regulative competence. Apart from the "usual suspect"-the national level - which in some cases actually needs to be split into two levels (federal and state), in the European context there are also institutionalized governing structures at the European level, e.g. the Bologna Follow Up Group (BFUG), which has a broader membership than only members of the EU, or the Culture and Education Committee of the European Parliament. Moreover, there are regional initiatives between different countries (i.e. the Nordics or Benelux) that in some policy areas have developed distinct regional approaches. The multi-level aspect also recognizes that there may be differences in how authority is distributed across levels and does not consider distribution of authority as a zero-sum game - e.g. most authority remains at the national level, but more and more decisions are taken at other levels as well.

2. Multi-actor characteristic-it is necessary to acknowledge both the heterogeneity of the "state" and its many composite institutions, as well as the involvement of non-state actors (e.g. stakeholder organizations, businesses, consumers) in a policy domain. Here, one should first identify the actors who are formally recognized as "insiders" in decision-making (Dür and Mateo 2016) e.g. the European Commission (a full member of the BFUG) or the six European stakeholder organizations, ${ }^{1}$ UNESCO and the Council of Europe that have consultative status in the BFUG. However, a wider net should be cast so that actors which vie for influence but may not have a formal position in the different governing structures (i.e. "outsiders") can also be included, e.g. a student union in a country in which students do not take part in the governing process and are not systematically consulted.

3. Multi-issue characteristic - one should identify how clashes as well as complementarities between policy sectors move into and away from the policy domain of interest. This requires a detailed analysis of the policy development

\footnotetext{
${ }^{1}$ They are: BUSINESSEUROPE, Education International (EI), the European Association for Quality Assurance in Higher Education (ENQA), the European Students' Union (ESU), the European University Association (EUA), and the European Association of Institutions in Higher Education (EURASHE).
} 
process in the focal higher education sector, monitoring which issues are put on the agenda, and whether they actually are core higher education issues or are spillovers from other sectors. It can also be done through monitoring whether actors linked to other policy sectors (e.g. ministries of finance, migration agencies, unemployment offices) take part in higher education policy development, and whether actors from higher education take part in policy development in other sectors, e.g. EHEA stakeholder organizations taking part in discussions on European migration. In this, the identification of multiple actors facilitates the identification of multiple issues.

It should be stressed that these three "multi characteristics" can be conducive to policy dynamics - e.g. the fact that actors can choose at which level or within which sector to push for a specific policy development can lead to policy changes despite formal obstacles or a lack of explicit jurisdiction (Elken 2015). However, each of the characteristics can also lead to deadlocks, standstills and similar coordination challenges (Peters 2015), in cases in which the actors cannot agree on the route to take, at what level a specific development should be discussed or which sector should take the lead.

In our view, analyses of European higher education governance, processes leading to particular arrangements and consequences thereof require unpacking three distinct characteristics of this very coordination - multi-level, multi-actor, and multi-issue - and addressing them separately from one another as an independent perspective, and recognizing their interaction as likely to be responsible for the outcomes observed. This means that, in total, there are seven potential variations of "multi" features that are of interest when examining governance of EHEA: (1) multi-level, (2) multi-actor, (3) multi-issue, (4) multi-actor and multi-issue, (5) multi-actor and multi-level, (6) multi-issue and multi-level, and (7) multi-actor, multi-issue, and multi-level.

Three of these interactions in the context of the EHEA-(a) multi-actor and multi-issue, (b) multi-actor and multi-level, (c) multi-issue and multi-level—will be illustrated with empirical examples in the remainder of the chapter. The illustrations show how the three multi-s can be the basis for novel avenues of research that have not yet received sufficient attention.

\section{The Three "Multi-S" in Action}

\section{Multi-actor and Multi-issue: Political Saliency of the EHEA}

The first aspect of governance in the EHEA that will be discussed concerns its political salience for national level policy actors, i.e. ministries responsible for higher education, as well as transnational non-state actors, i.e. European stakeholder organizations. As argued by Vukasovic et al. (2017), one of the ways in which the political salience of the EHEA can be assessed is to analyse who is representing the 
different actors at the key decision-making meetings - in this case, the ministerial conferences - and how this has changed over time. This approach reflects more general studies of political salience of European level policy developments (see e.g. Grøn and Salomonsen 2015), in which the basic premise is that the political rank of those "sitting at the table" matters, as well as that for successful lobbying it is often important to show both "strength in rank" as well as "strength in numbers".

Taking this as the starting point, Vukasovic et al. (2017) argued that political salience of the EHEA is comprised of two distinct dimensions: (a) a substantive and (b) a symbolic one. The substantive dimension reflects the fact that policies developed at the European level have an impact on both higher education systems and institutions, and thus both national and transnational actors are interested in shaping this process. The symbolic dimension highlights that participation and influence in the process send strong normative signals concerning (1) the importance of European level coordination of higher education policies for national and institutional level changes, and (2) the relevance of and rationale for policy activities (and therefore existence) of European stakeholder organizations. These two aspects combined also provide opportunities that participation and recognition of European stakeholder organizations on the European level are used as a symbolic resource by domestic stakeholder organizations to boost their own legitimacy and standing in their own domestic policy arenas. ${ }^{2}$

However, variance in both dimensions of salience is expected across:

- time, due to gradual consolidation of EHEA governance structures, but more importantly for this discussion, continuous elaboration of policy issues and preferences developed by these structures as well as EU institutions;

- space, because for EU Member States, the pan-European EHEA governing structure is not the only platform available for European level coordination, while this is not the case for countries that are not likely to become part of the EU (e.g. Russia or the South Caucasus countries);

- types of policy actors, as national level actors and transnational non-state actors have different rationales for participation in the process.

Thus, Vukasovic et al. (2017) focused on several patterns of interest, including: (1) changes in average size and rank of national delegations over time, (2) comparison between rank and size of national delegations of EU members, candidate countries and potential members, and (3) changes in size of delegation of European stakeholder organizations. Analysing participation at the ministerial conferences between 1999 and 2015, they found that average size and rank of national delegations did indeed decrease over time, that in recent years unlikely EU members and potential EU candidates have been sending higher-ranking delegations to ministerial summits than candidates or EU members, and that the size of delegations of European stakeholder organizations have been relatively stable since 2007 .

\footnotetext{
${ }^{2}$ See Chou et al. (2016) for analytic similarities regarding policy failures.
} 
Such variance is indicative of the interaction between multi-actor and multi-issue aspects of the EHEA's governance. Namely, the evolution of the EHEA policy agenda from the initial six, relatively ambiguous, action lines to ten action lines and rather specific preferences concerning various aspects of higher education, including those that are of interest to other policy sectors (e.g. migration, employment) signifies very clearly the multi-issue aspect. Moreover, some of the issues - such as the qualifications frameworks - have been dealt in two separate (somewhat interrelated) arenas, the pan-European EHEA and the policy arena embedded within the EU framework. This means that some of the multiple actors taking part in EHEA governance have a choice in terms of which issue to purse within which policy arena. As suggested by Vukasovic et al. (2017), this is one possible explanation for the decline in the rank of the delegations of EU Member States. While European stakeholder organizations can theoretically do the same, their choice comes with more constraints. This is because they are officially recognized as legitimate actors in the EHEA arena (as indicated by their formal status as consultative members in the BFUG), while within the EU institutions their access to all relevant decision-makers is not guaranteed (Vukasovic, forthcoming in 2018). This adds a multi-actor aspect, implying that changes in the political salience of the EHEA may be accounted for by the fact that interactions between multi-issue and multi-actor aspects of EHEA governance play out differently across time, across space (for different national-level actors) and across different European stakeholder organizations. While these analyses provide first steps into unpacking the role and behaviour of various actors, there is also a need to further and expand this research agenda.

\section{Multi-level and Multi-actor: European Stakeholder Organizations as Meta-Organizations}

The second aspect concerns six European stakeholder organizations that are consultative members of the BFUG, i.e. BusinessEurope, EI, ENQA, ESU, EUA, and EURASHE. As previously indicated, the involvement of stakeholder organizations as such (regardless of the governance level) is reflective of the multi-actor aspect of governance and highlights the fact that policy development also involves mediation between interests of different stakeholder groups. However, European stakeholder organizations, given that their members are national or local stakeholder organizations or, in the case of EUA and EURASHE, higher education institutions, are actually organizations of other organizations, i.e. they are meta-organizations (Ahrne and Brunsson 2005). This means that they are multi-level organizations themselves and thus their participation and influence in the governance structures of the EHEA reflect the interaction between multi-actor and multi-level aspects of governance. 
The key implication of this is that European stakeholder organizations constitute an additional link between different governance levels, thus providing a channel through which interest intermediation at one level can affect interest intermediation at the other. This first concerns the status of stakeholder organizations in their respective policy arenas. For example, in order to become recognized on the European level as a representative of students, ESU had to argue that its members are both representative and recognized in their own national contexts (Elken and Vukasovic, 2014; Klemenčič 2012). Moreover, given that the key struggle to be recognized as an actor took place prior to the Prague Ministerial Summit in 2001, it was important that, inter alia, (1) the Czech member of ESU (SKRVS), i.e. the student union from the country organizing the ministerial conference, and (2) the Swedish member of ESU (SFS), i.e. the student union from the country presiding the EU in that period, were at that point recognized as partners in higher education governance in their own national contexts and could use their "insider" position to support ESU's claim for involvement in the EHEA governing structures. Thus, while at the Bologna Ministerial Summit in 1999, ESU representatives were present only in an unofficial manner, in Prague ESU's chairperson was one of the keynote speakers and students were recognized as key partners in the process (Bologna Process 2001). ${ }^{3}$ This enabled ESU to push for a stronger focus on student participation in governance, and together with some allies - the Council of Europe and some EHEA countries - promote the practice of some of the national delegations to include student representatives as a recommendation for all national delegations. This was in turn used by some ESU members to argue for improvement of their own position in their national policy arenas. Among others, the Student Union of Serbia used its membership in ESU and recognition of ESU as the student representative in the Bologna Process to strengthen its claim for participation in the governance of HE in Serbia (Branković 2010).

Another aspect in which the European stakeholder organizations provided a link between interest intermediation at various governance levels concerns the development of policy positions. Given that the key purpose of these organizations is advocacy and influence, their policy positions constitute their main organizational outputs and act as signalling devices both towards the European decision-makers as well as towards their own membership (Vukasovic 2017). Similar to the relationship between EU institutions and Member States, policy positions of European stakeholder organizations are often the result of some of their members "uploading" their policy preferences to the European level, while other members may be "downloading" the European level policy positions to apply them in their national contexts (for a more general discussion of uploading and downloading, see Börzel 2003). The lack of systematic research regarding the relationship between stakeholder organization policy development at various governance levels has also major

\footnotetext{
${ }^{3}$ ESU (then ESIB) pushed for its inclusion in the EHEA governance structures by other means as well, including providing expert advice through its Committee on Prague in 2001 and later the Bologna Process Committee.
} 
consequences. First, this means that there is still a limited systematic understanding and conceptualization of where specific policy ideas come from and how they might be adapted and translated by different actors operating across governance levels. Second, analysis of the democratic legitimacy of European decision-making in this context has not sufficiently taken into account the role of members in developing positions of European stakeholder organizations, as well as comparing positions of European stakeholder organizations and their members. There are great expectations in this respect, and Elken and Vukasovic (2014) argue that this was the reason why most of the stakeholder organizations were granted consultative status in the BFUG in the first place. Yet, research on such organizations implies we should be more cautious. This is because (1) the legitimacy expectation relies on the assumption that the "long chain of delegation" (Kohler-Koch 2010) between grass-roots and Brussels works well and this is not necessarily a given, and that (2) there is actually "nothing intrinsically democratic" about such organizations (Binderkrantz 2009: 658). Thus, while enhancement of democratic legitimacy might be a means for gaining access, the consequences of this need to be studied in much more detail. One way of assessing the extent to which European stakeholder organizations contribute to the democratic legitimacy of European decision-making is to study governance arrangements of these organizations, in particular concerning development of policy positions, as well as to assess the congruence between their policy positions and policy positions of their members.

\section{Multi-issue and Multi-level: Policy Coordination and Convergence on Regional and European Levels}

The third aspect of interest is based on the necessity to take a closer look at the different levels of governance of higher education in Europe. While there are studies which focus on commonalities and differences between countries with cultural, economic and political similarities (e.g. Branković et al. 2014; Christensen et al. 2014; Dobbins and Khachatryan 2015; Dobbins and Knill 2009; Vukasovic and Elken 2013; Vukasovic and Huisman 2017; Zgaga et al. 2013), the role of regional arrangements in the European Higher Education has not been systematically studied.

With this in mind, Elken and Vukasovic (forthcoming in 2018) compare (a) policy coordination and convergence at the European level with (b) policy coordination and convergence within four European regions: the Balkans, the Baltic countries, Benelux and the Nordic countries. The four regions exhibit a complex mix of similarities and differences in their policy developments and thus are suitable for exploring policy coordination and policy convergence in a more nuanced way. Two of them - the Balkans and the Baltic countries-belong to what is sometimes still termed as post-Communist Europe and are in general poorer than the other two regions-Benelux and the Nordic countries-which frequently come on top of 
various prosperity, human development and democratic stability rankings. Given their geographical proximity, these regions shared historical legacies: Socialist Federal Republic of Yugoslavia (SFRY) for the Balkans, Union of Soviet Socialist Republics (USSR) for the Baltic countries, Danish or Swedish rule for most of the Nordic countries and, among others, the United Kingdom of the Netherlands for the Benelux. These historical legacies have also contributed to their cooperation following the dissolution of earlier political configurations: for instance, the Benelux is a political and economic union that predates the EU, the Nordic countries have been coordinating their policies through the Nordic Council of Ministers (and a Nordic Passport Union has been in existence since 1952), the Baltic countries have had a similar structure in place since the early 1990s, while in the Balkans the Regional Cooperation Council was set up in 2008 in order to achieve more integration. At the same time, the regions differ with regards to their position towards the EU, with the Benelux countries being some of the founders, while all of the Baltic countries and some of the Balkan and Nordic countries became members (much) later.

Elken and Vukasovic (forthcoming in 2018) complement the analysis of three governance levels with analysis of multi-issue aspects, i.e. similarities and differences of interrelated policies: quality assurance, qualifications frameworks and recognition of qualifications. The study finds that policy development in the Balkans does not go towards increasing similarity within the region, but rather a convergence with European level developments concerning the three issues. For the Baltic countries, the situation is somewhat different, given the close cooperation between QA agencies and the AURBELL ${ }^{4}$ project focusing on automatic recognition. Benelux exhibits strong convergence within the region concerning recognition of qualifications (automatic recognition is already in place) and partially quality assurance, given the fact that the Flemish Community of Belgium and the Netherlands have a joint QA agency (NVAO). For the Nordic region, the developments concerning automatic recognition are similar to the Baltics-there is commitment but at the time of writing a decision has not been reached, while NOQA (the Nordic Quality Assurance Network in Higher Education) that has existed since 1992 has been a basis for some convergence.

In light of the fact that studies about the implementation of the Bologna Process continue to report that there is "surface convergence, persistent diversity underneath" (European Commission/EACEA/Eurydice 2015; Westerheijden et al. 2010; Witte 2006, 2008), the lack of systematic analysis of the regional level coordination in relation to national level policy changes and European integration initiatives means that a possible explanation for varied patterns has not been sufficiently analysed. Moreover, the regional level matters in different ways for different policy issues, thus clearly highlighting one of the implications of the interaction between multi-level and multi-issue dimensions of governance in the EHEA.

\footnotetext{
${ }^{4}$ Automatic Recognition between Estonia, Latvia and Lithuania project.
} 


\section{What's Next? Expanding the Analysis of the Bologna Process}

Since 1999, the Bologna Process has expanded considerably. Yet, the analytical toolbox to analyse these developments has not followed suit. This chapter argues that, in order to understand the intricacies and nuances of governance of higher education, it is necessary to conceptually distinguish between three dimensions: (1) the multi-level dimension concerning how authority is distributed or concentrated across governance levels, (2) the multi-actor dimension which highlights heterogeneity of state and the involvement of non-state actors (e.g. stakeholder organizations, businesses, consumers), and (3) the multi-issue dimension which concerns clashes as well as complementarities between policy sectors. The potential of the "three multi-s" framework to improve our knowledge of European higher education policy developments has been demonstrated through (a) analysis of changing political salience of the EHEA, (b) exploration of the role of European stakeholder organizations, and (c) consideration of the regional policy coordination and convergence in relation to European level developments. While each of these developments can be analysed on its own, the umbrella framework of the "three multi-s" allows us to see them as interrelated and more general European developments. Moreover, these examples show how the multi-framework also allows for a new focus of analysis.

While the focus of this chapter has been on European developments, the "three multi-s" are not contextually bound and can be employed for analysis of similar integration dynamics in other macro-regions of the world, e.g. South East Asia (as demonstrated by Chou and Ravinet 2017), or for exploring inter-regional interactions. Moreover, analysing EHEA governance in a comparative manner (and not as sui generis) can be conducive to a deeper understanding of EHEA, with regard to both its commonalities with other regional integration projects and its specificities. With further studies, we may begin to address emerging questions that are engaging scholars in recent years, such as: Are concepts such as "academic freedom" unique to Europe or the West? What about the institution of the University, to what extent is this a European idea? How can we reconcile deep policy developments in Europe and its centuries-old universities with the rise of Asia, especially its younger universities that have been climbing the international rankings in meteoric ways? By engaging in such comparative research, it is also possible to enhance and nuance our understanding of the developments within EHEA.

Looking into the future, we expect that the governance of EHEA — should it continue - to persistently exhibit complexity with regards to governance structures as well as actor constellations - with sometimes diverging and sometimes converging interests, depending on the issue at hand. The expansion of the process to 48 countries has only added to this complexity, given that with every additional country the complexity increases as different actors, regions or issues are included in the EHEA. Given this increasing complexity and the need for unanimous agreement by all full members of the EHEA to ministerial communiqués, it is very 
likely that agreements between the different actors on concrete policies will become harder if their interests remain divergent. Thus, we are most likely going to continue to observe rather ambiguous European policies as well as variations in national and organizational implementation. Moreover, one can also expect that responses on regional level could become a stepping stone in the context of EHEA as a whole. At the same time, it is less likely that the increased number of countries will be able to agree on new comprehensive action lines for the EHEA, but rather focus on technical aspects, for example detailed development of the existing tools in the area of quality assurance or qualification frameworks. EU efforts to consolidate the European Education Area by, among other things, launching the Sorbonne process for mutual recognition is, in this context, an interesting development and emphasizes the necessity of a multi-actor and multi-issue approach to analysing the Bologna Process.

To what extent would the complexity and ambiguity of future EHEA governance contribute to its vulnerability remains to be examined. However, we contend that the conceptualization of the "three multi-s" offered in this chapter and the discussion of their interactions provide a more robust analytical tool for understanding the past, current, and future developments of the EHEA as well as its implications for higher education in and beyond Europe.

\section{References}

Ahrne, G., \& Brunsson, N. (2005). Organizations and meta-organizations. Scandinavian Journal of Management, 21(4), 429-449.

Binderkrantz, A. S. (2009). Membership recruitment and internal democracy in interest groups: Do group-membership relations vary between group types? West European Politics, 32(3), 657-678.

Bologna Process. (2001). Towards a European Higher Education Area: Communiqué of the meeting of European Ministers in charge of Higher Education. Prague.

Börzel, T. A. (2003). Shaping and taking EU policies: Member State responses to Europeanization. Paper presented at the Queen's Papers on Europeanisation.

Branković, J. (2010). Decision making on decision making: Deciding governance in higher education in Serbia 2002-2005. University of Oslo.

Branković, J., Kovačević, M., Maassen, P., Stensaker, B., \& Vukasovic, M. (2014). Re-Institutionalization of Higher Education in the Western Balkans: The interplay between European ideas, domestic policies, and institutional practices. Frankfurt: Peter Lang.

Braun, D. (2008). Organising the political coordination of knowledge and innovation policies. Science and Public Policy, 35(4), 227-239.

Busemeyer, M. R., Franzmann, S. T., \& Garritzmann, J. L. (2013). Who owns education? Cleavage structures in the Partisan competition over educational expansion. West European Politics, 36(3), 521-546. https://doi.org/10.1080/01402382.2012.753703.

Chou, M.-H. (2012). Constructing an internal market for research through sectoral and lateral strategies: Layering, the European Commission and the fifth freedom. Journal of European Public Policy, 19(7), 1052-1070.

Chou, M.-H., \& Gornitzka, A. (2014). Building the knowledge economy in Europe: New constellations in European research and higher education governance. Cheltenham: Edward Elgar. 
Chou, M.-H., Howlett, M., \& Koga, K. (2016). Image and substance failures in regional organisations: Causes, consequences, learning and change? Politics and Governance, 4(1), $50-61$.

Chou, M.-H., Jungblut, J., Ravinet, P., \& Vukasovic, M. (2017). Higher education governance and policy: an introduction to multi-issue, multi-level and multi-actor dynamics. Policy and Society, 36(1).

Chou, M.-H., \& Ravinet, P. (2015). Governing higher education beyond the state: The rise of 'Higher education regionalism. In H. De Boer, D. D. Dill, J. Huisman, \& M. Souto-Otero (Eds.), Handbook of Higher Education Policy and Governance (pp. 361-378). London: Palgrave.

Chou, M.-H., \& Ravinet, P. (2017). Higher education regionalism in Europe and Southeast Asia: Comparing policy ideas. Policy and Society, 36(1), 143-159.

Christensen, T. (2011). University governance reforms: Potential problems of more autonomy? Higher Education, 62(4), 503-517.

Christensen, T., Gornitzka, Å., \& Maassen, P. (2014). Global pressures and national cultures: A Nordic University Template. In P. Mattei (Ed.), University adaptation in difficult Economic Times. Oxford: Oxford University Press.

Dobbins, M., \& Khachatryan, S. (2015). Europeanization in the "Wild East"? Analyzing higher education governance reform in Georgia and Armenia. Higher Education, 69(2), 189-207.

Dobbins, M., \& Knill, C. (2009). Higher education policies in Central and Eastern Europe: Convergence towards a common model. Governance, 22(3), 397-430.

Dür, A., \& Mateo, G. (2016). Insiders versus outsiders: Interest group politics in multilevel Europe. New York: Oxford University Press.

Elken, M. (2015). Developing policy instruments for education in the EU: The European qualifications framework for lifelong learning. International Journal of Lifelong Education, 34 (6), 710-726.

Elken, M., \& Vukasovic, M. (2014). Dynamics of voluntary policy coordination: The case of Bologna Process. In M. H. Chou \& A. Gornitzka (Eds.), The Europe of knowledge: Comparing dynamics of integration in higher education and research policies (pp. 131-159). Cheltenham: Edward Elgar.

Elken, M., \& Vukasovic, M. (2018). Coordination and convergence of higher education policy in a multi-level governance context. Dordrecht: Springer.

European Commission, EACEA, Eurydice. (2015). The European Higher Education Area in 2015: Bologna Process Implementation Report.

Gornitzka, Å., \& Maassen, P. (2014). Dynamics of convergence and divergence: Exploring accounts of higher education policy change. In P. Mattei (Ed.), University adaptation in difficult Economic Times (pp. 13-29). Oxford: Oxford University Press.

Grøn, C. H., \& Salomonsen, H. H. (2015). Who's at the table? An analysis of ministers' participation in EU Council of Ministers meetings. Journal of European Public Policy, 22(8), 1071-1088.

Hooghe, L., \& Marks, G. (2003). Unraveling the Central State, but how? Types of multi-level governance. American Political Science Review, 97(2), 233-243.

Jungblut, J. (2015). Bringing political parties into the picture: A two-dimensional analytical framework for higher education policy. Higher Education, 69(5), 867-882.

Klemenčič, M. (2012). The changing conceptions of student participation in HE Governance in the EHEA. In A. Curaj, P. Scott, L. Vlasceanu, \& L. Wilson (Eds.), European higher education at the crossroads: Between the Bologna Process and national reforms (pp. 631-653). Dordrecht: Springer.

Kohler-Koch, B. (2010). Civil society and EU democracy: 'Astroturf' representation? Journal of European Public Policy, 17(1), 100-116.

Maassen, P. (2003). Shifts in governance arrangements: An interpretation of the introduction of new management structures in higher education. In A. Amaral, L. Meek, \& I. M. Larsen (Eds.), The higher education managerial revolution? (pp. 31-55). Dordrecht: Kluwer Academic Publishers. 
Maassen, P., Gornitzka, Å., \& Fumasoli, T. (2017). University reform and institutional autonomy: A framework for analysing the living autonomy. Higher Education Quarterly advance online publication, June 15. https://doi.org/10.1111/hequ.12129.

Maassen, P., \& Olsen, J. P. (2007). University dynamics and European integration. Dordrecht: Springer.

Peters, B. G. (2015). Pursuing horizontal management: The politics of public sector coordination. Kansas: University Press of Kansas.

Piattoni, S. (2010). The theory of multi-level governance: Conceptual, empirical, and normative challenges. Oxford: Oxford University Press.

Vukasovic, M. (2017). Stakeholder organizations in the European higher education area: Exploring transnational policy dynamic. Policy and Society, 36(1), 109-126.

Vukasovic, M. (2018). European-level policy dynamics in higher education. In N. Zahariadis \& L. Buonanno (Eds.), The Routledge Handbook of European Public Policy (pp. 373-380). London: Routledge.

Vukasovic, M., \& Elken, M. (2013). Higher education policy dynamics in a multi-level governance context: A comparative study of four post-communist countries. In P. Zgaga, U. Teichler \& J. Brennan (Eds.), The globalisation challenge for European higher education. Convergence and diversity, centres and peripheries (pp. 261-286). Frankfurt am Main: Peter Lang Verlag.

Vukasovic, M., \& Huisman, J. (2017). Europeanization, policy transfer or domestic opportunity? Comparison of European impact in Higher Education Policy. Journal of Comparative Policy Analysis: Research and Practice advance online publication May 19. https://doi.org/10.1080/ 13876988.2017.1320132.

Vukasovic, M., Jungblut, J., \& Elken, M. (2017). Still the main show in town? Assessing political saliency of the Bologna Process across time and space. Studies in Higher Education, 42(8), $1421-1436$.

Westerheijden, D. F., Beerkens, E., Cremonini, L., Huisman, J., Kehm, B., \& Kovač, A., et al. (2010). The first decade of working on the European Higher Education Area: Executive summary overview and conclusions.

Witte, J. (2006). Change of degrees and degrees of change. PhD dissertation, Center for Higher Education Policy Studies: University of Twente.

Witte, J. (2008). Aspired convergence, cherished diversity: Dealing with the contradictions of Bologna. Tertiary Education and Management, 14(2), 81-93.

Zgaga, P., Klemenčič, M., Komljenovič, J., Miklavič, K., Repac, I., \& Jakačić, V. (2013). Higher Education in the Western Balkans: Reforms, developments, trends. Ljubljana: Center for Education Policy Studies.

Open Access This chapter is licensed under the terms of the Creative Commons Attribution 4.0 International License (http://creativecommons.org/licenses/by/4.0/), which permits use, sharing, adaptation, distribution and reproduction in any medium or format, as long as you give appropriate credit to the original author(s) and the source, provide a link to the Creative Commons license and indicate if changes were made.

The images or other third party material in this chapter are included in the chapter's Creative Commons license, unless indicated otherwise in a credit line to the material. If material is not included in the chapter's Creative Commons license and your intended use is not permitted by statutory regulation or exceeds the permitted use, you will need to obtain permission directly from the copyright holder.

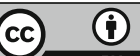

